\title{
Tensile Strength, Elasticity and Cracking Character of Softwood Tissues
}

\author{
Viktorija DAKNEVIČIŪTĖ, Daiva MILAŠIENĖ, Kristina UKVALBERGIENE் *
}

Department of Materials Engineering, Kaunas University of Technology, Studentu str. 56, LT-51424 Kaunas, Lithuania

crossref http://dx.doi.org/10.5755/j01.mm.21.2.6881

Received 05 April 2014; accepted 19 September 2014

\begin{abstract}
Wood tensile strength in longitudinal direction depends on wood density and structure. Growth rings in wood consist of earlywood and latewood, which differ greatly in their properties. Latewood is denser, less porous and more resistant to tension along the fiber compared to earlywood. The ratio of latewood and earlywood is different for each type of wood species and also depends on growing conditions, climate and etc. The study is aimed to evaluate the tensile strength, elasticity and cracking character of Lithuanian-grown softwood tissues, depending on the wood species, tissue width and latewood ratio in the sample. For the study three species of wood (spruce, pine and larch) were chosen. Samples were cut with the microtome, tissues cross-sectional area of about $0.15 \mathrm{~mm}^{2}-0.50 \mathrm{~mm}^{2}$. The ratio of latewood and earlywood was evaluated using microscope. Wood tissue tensile strength was tested in the tensile machine with a feed rate of $0.2 \mathrm{~mm} / \mathrm{min}$. Research results showed that the highest tensile strength was obtained for larch wood samples, while the spruce wood most tended to deformation. It was determined that the tensile strength and elasticity of wood are highly influenced by wood microstructure and earlywood and latewood ratio in the sample. Also the wood microstructure and failure mechanism of the samples were evaluated.

Keywords: tensile strength, tissue, softwood, latewood, failure.
\end{abstract}

\section{INTRODUCTION}

Currently it is still a lack of knowledge for understanding the behaviour of wood in macroscopic level in dependence of its microscopy. Moreover, the anisotropy, heterogeneity and hygroscopicity of wood complicate the prediction of wood behaviour in long terms as well as creation of simplified models. Advanced technologies allow understanding micro- and nanostructure of wood. It becomes possible to understand wood cell wall deformation behaviour in dependence on various external parameters. In this study the coniferous wood was investigated.

Main structural element of softwood tissues are tracheids in average of $2 \mathrm{~mm}-6 \mathrm{~mm}$ in length and in diameter of $20 \mu \mathrm{m}-40 \mu \mathrm{m}$. The major component of tracheid`s wall are crystalline cellulose fibrils (about 50 $\%)$, that are twisted around the longitudinal axis of the wood cell at a certain angle, called microfibril angle [1, 2]. It varies depending on the tree species and highly affects mechanical properties as well as elasticity of wood.

Examination of the microstructure of Norway spruce (Picea abies L.) showed that cell wall thickness is not uniform throughout the length of the tracheid. The thickness of tangential wall tends to be thicker $(1.6 \%-13.6 \%)$ in the areas that are crossed by pith rays (called cross-field zones) [3]. Also cell wall thickness increases from pith to bark. The tensile tests on the radial cells of beech wood (Fagus sylvatica L.) showed that pith rays have a significant effect on the tensile strength of wood in the tangential direction [4]. Also mechanical properties of wood are strongly influenced by wood density. It varies in the growth ring latewood is denser than earlywood areas due to thicker cell walls and smaller diametre of fibers [5]. As concerning features of wood microstructure, the mechanism of latewood

\footnotetext{
* Corresponding author. Tel.: +370-37-300040; fax.: +370-37-353863.

E-mail address: kristina.ukvalbergiene@ktu.lt (K. Ukvalbergienè)
}

and earlywood fiber fracture is different [6, 7]. Wood fibers creep behaviour and tensile strength is affected by moisture content of the fibers [8]. The photodegradation of wood tissues also leads to a significant loss of tensile strength [9]. Investigating the mechanical properties of thin compression wood foils and isolated tracheids of spruce (Picea abies L.), ginkgo (Ginkgo biloba L.), yew (Taxus baccata L.) and juniper (Juniperus virginiana L.) wood showed, that spruce foils and tracheids are the most elastic compared to other studied species, while the most impact on the micromechanical properties has microfibril angle (MFA) [10]. In the other work deformation and energy absorption of spruce cell walls under tensile loading was analyzed [11]. Results showed that with increasing MFA, longitudinal fracture strain also increases, while tensile strength decreases. Other researches studied the tensile behaviour of compression, mature and juvenile spruce wood cells [12]. After cyclic tensile tests were done, it was determined that beyond the yield point, the tracheid undergoes a large mainly irreversible deformation, and the stiffness of tracheid increases. Compression wood tracheids have much lower stiffness and higher strain than normal wood tracheids. Also experiments showed that tracheids have load-history dependancy. Crack initiates in the weakest zones of the wood cell. In other work the stiffness of transition fibers, tissues and solid wood of yew (Taxus baccata L.) and spruce (Picea abies L.) wood was compared [13]. It was determined that the MOE based on the cell wall area for spruce wood is about $50 \%$ higher than for yew and respectively MOE based on the total cross-sectional area is about $20 \%-30 \%$ lower for yew than for spruce fibers.

Most of the studies are done on the macro level and it is not exactly known how wood behaves on the micro level. Another problem encountered in the studies of wood properties in the micro level - it is not known exactly what causes the ultimate result - whether the properties of wood 
or the procedures of sample preparation [14]. The objective of this work was to investigate the impact of wood species, tissue width and late/earlywood ratio to tensile strength, elasticity and cracking character of Lithuania-grown softwood tissues.

\section{MATERIALS AND METHODS}

For the investigation typical coniferous wood species grown in Lithuania area such as pine $P$ (Pinus sylvestris L.), spruce $S$ (Picea abies L.) and larch $L$ (Larix L.), age of 80 years were selected. The density of pine wood was $367 \mathrm{~kg} / \mathrm{m}^{3}$, for spruce wood it was $468 \mathrm{~kg} / \mathrm{m}^{3}$, whereas the density of larch wood was $685 \mathrm{~kg} / \mathrm{m}^{3}$. In the longitudinal tangential direction thin specimens of $100 \mu \mathrm{m}$ in thickness, $30 \mathrm{~mm}$ in length and $5 \mathrm{~mm}$ in width were microtomed from the initial samples. Three groups of samples that varied in width (1.5, 2.5 and $5 \mathrm{~mm}$ ) and thickness $100 \mu \mathrm{m} \pm 5 \mu \mathrm{m}$ were prepared. From each sample using extrasharp razor the sections across the grain thereafter were sliced off. Cross sections, microstructure and late/earlywood ratio of the samples were examined with a scanning electron microscope FEI Quanta 200 FEG (SEM).

Prior to tensile testing all of the samples were initially conditioned at temperature $23^{\circ} \mathrm{C}$ and relative humidity of $65 \%$ for 24 hours. The ends of test specimens were glued with cyanoacrylate glue to the special holders that were later fixed in the grips of the testing machine (Fig. 1).

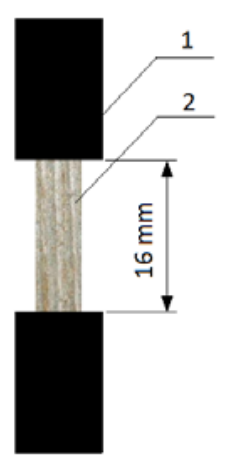

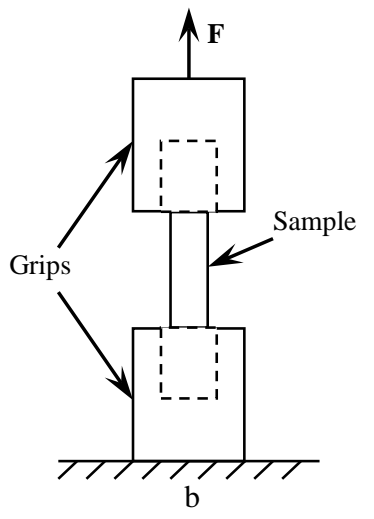

Fig. 1. Test sample: a - sample with special holders (1), working length $16 \mathrm{~mm}$ (2); b - sample anchoring in the machine grips

The specimen was subjected to uniaxial tension with cross-head speed of $0.2 \mathrm{~mm} / \mathrm{min}$ and operating length $16 \mathrm{~mm}$ until it fractures. Tensile strength was calculated using the following equation:

Error! Bookmark not defined.Error! Bookmark not defined. $\sigma=F / S$,

where $F$ is the tensile force, $\mathrm{N} ; S$ is the specimen crosssection area, $\mathrm{mm}^{2}$.

Tensile tests were performed with a universal testing machine P10T (Germany) using a force sensor up to $4 \mathrm{~N}$.

\section{RESULTS AND DISCUSSION}

For the tests 30 samples for one wood species were prepared (in total 90 samples). Prior to tensile testing the microstructure was evaluated as well as the area of cross section and the percentage of latewood in the sample was measured (Fig. 2).
In Fig. 2 it can be seen cells of earlywood and latewood, wall thickness, cavities, cells` shape are presented. The distribution of pine late- and earlywood cells (Fig. 2, b, e) is similar to the spruce (Fig. 2, a, d), however in tangential direction spruce cells are thicker and wider in diameter compared to the pine cells, while in radial direction pine earlywood cells are larger in diameter. Larch wood properties are slightly different from pine and spruce wood (Fig. 2, c, f). Tracheids are shorter but have larger diameter in radial and tangential directions. Larch latewood cells are larger and have thicker walls than other coniferous species, consequently larch wood is much denser than spruce and pine wood, and has higher modulus of elasticity (larch $13.8 \mathrm{GPa}$, spruce $10 \mathrm{GPa}-11 \mathrm{GPa}$, pine $11 \mathrm{GPa}-12 \mathrm{GPa}$ ) [15-17]. Transition from early- to latewood of larch wood is abrupt, while for spruce and pine gradual transition is characteristic.

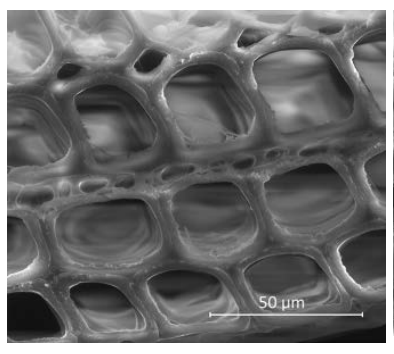

a

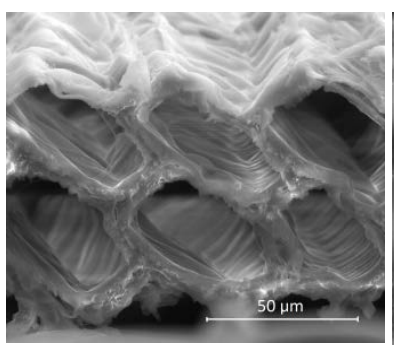

C

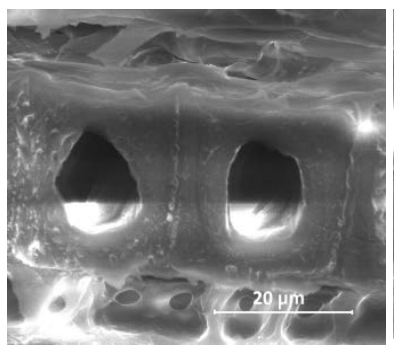

e

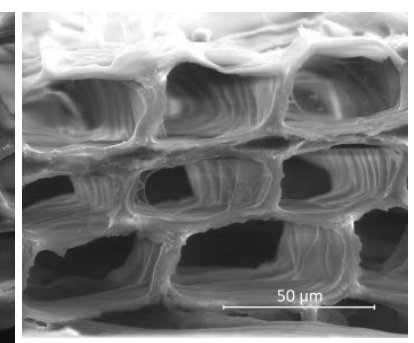

b

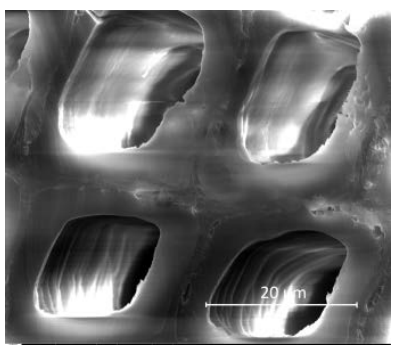

d

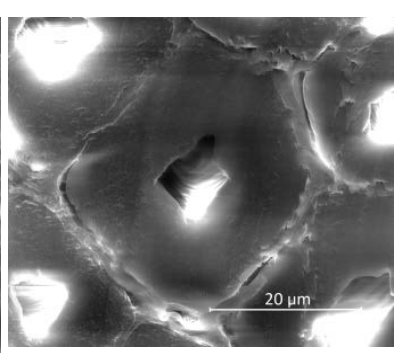

$\mathrm{f}$
Fig. 2. SEM micrographs of cross sections of earlywood: a - spruce, b - pine, c - larch; latewood: d - spruce, $\mathrm{e}$ - pine, $\mathrm{f}$ - larch

Tensile tests results are presented in Table 1 . From Table 1 it can be seen that maximum tensile force is required for larch wood, while the lowest - for pine wood. Larch wood tissues to be fractured need higher strength $14 \%-27 \%$ compared to the spruce samples and $40 \%-50 \%$ compared to the pine samples. This could be explained by significantly higher density (about 1.9 times) and the microstructure of larch wood. The studies of the tensile strength of wood in the macro level show that wood density as well as wood fiber direction strongly influence the 
strength of wood [18]. The obtained study results do not contradict the results delivered by other authors [10, 21].

In Table 1 it can be seen that with the increasing of the sample's width from $1.5 \mathrm{~mm}$ to $5 \mathrm{~mm}$, tensile strength increases by $20.43 \%$ for spruce, $32.88 \%$ for pine and $19.48 \%$ for larch respectively. Statistical analysis of the results shows that the highest coefficient of variation is for larch wood (up to $6.58 \%$ ), while for the spruce wood up to $3.23 \%$, and pine wood - up to $1.97 \%$.

Table 1. The tensile strength of spruce $(S)$, pine $(P)$ and larch $(L)$ wood

\begin{tabular}{|l|c|c|c|c|}
\hline Sample & $\begin{array}{c}\text { Tensile } \\
\text { strength } \\
\sigma, \mathrm{MPa}\end{array}$ & $\begin{array}{c}\text { Coefficient } \\
\text { of variation } \\
V, \%\end{array}$ & $\begin{array}{c}\text { Relative } \\
\text { elongation } \\
\varepsilon, \%\end{array}$ & $\begin{array}{c}\text { Cross- } \\
\text { section area } \\
S, \mathrm{~mm}^{2}\end{array}$ \\
\hline$S_{\text {av }} 1.5^{*}$ & 37.83 & 1.62 & 9.63 & 0.146 \\
\hline$S_{\text {av } 2.5}$ & 46.21 & 3.23 & 9.44 & 0.250 \\
\hline$S_{\text {av }} 5$ & 45.56 & 3.00 & 8.50 & 0.480 \\
\hline$P_{\text {av } 1.5}$ & 25.76 & 1.84 & 6.31 & 0.148 \\
\hline$P_{\text {av } 2.5}$ & 32.27 & 0.47 & 4.13 & 0.250 \\
\hline$P_{\text {av } 5}$ & 34.23 & 1.97 & 3.82 & 0.506 \\
\hline$L_{\text {av }} 1.5$ & 51.50 & 6.58 & 5.50 & 0.146 \\
\hline$L_{\text {av }} 2.5$ & 53.49 & 3.75 & 5.32 & 0.250 \\
\hline$L_{\text {av }} 5$ & 61.53 & 1.44 & 4.63 & 0.454 \\
\hline
\end{tabular}

Analysing obtained coniferous wood elongation results, it was determined that prior to failure spruce wood samples extend most $-8 \%-10 \%$, whereas pine wood samples $-3 \%-6 \%$, and larch $-4.5 \%-5 \%$. This shows that spruce wood is more prone to deformation and its cells are more elastic compared to the other studied species.

The typical tensile strength and relative elongation of the samples curves corresponding three types of wood species are presented in Fig. 3.

It can be seen from Fig. 3 that all types of wood samples have similar deformation curve. The major of the samples fracture immediately, but some of them crack in several stages. It depends on the internal wood structure, microfibrils angle of the cell wall as well as early- and latewood ratio in the sample.

It was noticed that earlywood zones tend to fracture in a straight line perpendicular to the fiber axis. Latewood areas break diagonally to the fiber direction. This shows that earlywood cells are identical or very similar in strength and fracture all at once, while latewood cells break in different areas, unevenly.

From the results it was observed that tensile strength is strongly influenced by the amount of the latewood in the sample - the major part of latewood is in the sample, the higher force is needed to break it. The evaluation of correlation between tensile strength and latewood amount in the sample showed that the intercoherence is quite strong (for spruce, pine and larch samples - from 0.826 to 0.949 , 0.773...0.955 and 0.806...0.934 respectively, Fig. 4).

Other studies show that the tensile strength of wood also depends on the microfibrile angle (MFA) in the cell wall layer S2 (middle layer of the secondary wall in the cell) - with the increasing of MFA by $5^{\circ}$, the tensile strength increases 1.2 times [19]. The tensile strength of the latewood at the same MFA is 3.2 times higher than earlywood.

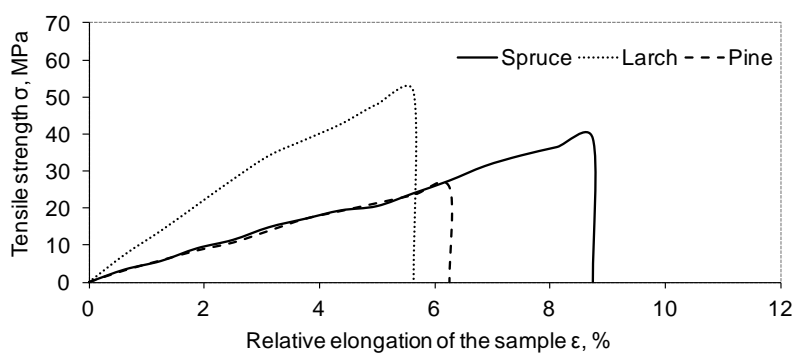

a

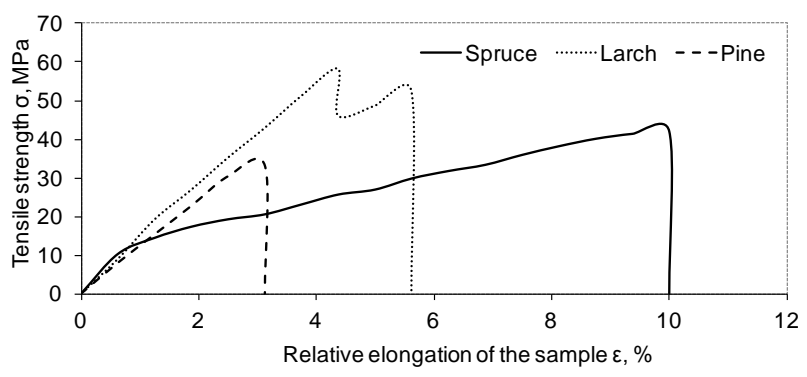

b

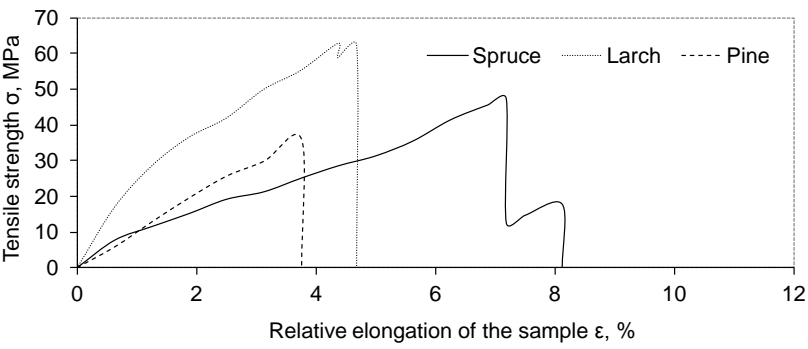

C

Fig. 3. Typical relative elongation of the sample and tensile strength curves, when cross-sectional area is: $\mathrm{a}-0.15 \mathrm{~mm}^{2}$, b $-0.25 \mathrm{~mm}^{2}, \mathrm{c}-0.48 \mathrm{~mm}^{2}$

Eder M. et al. tried to answer the question why latewood fibres break at considerably higher stress levels than earlywood fibres [6]. Scientists determined that fracture mechanisms of Norway spruce earlywood, latewood and transition wood cells are different. For thin-walled cells (earlywood) tension buckling initiated the crack and that was the common failure mechanism, while for thick-walled cells (latewood) tension buckling did not play the major role in the crack initiation. With the increasing cell wall thickness, more important for cracking became pits and other weak structural areas. Also it was obtained that tensile strength of latewood is $31 \%$ higher compared to earlywood cells and about $11 \%$ higher than transition wood cells. In the other work [7], studying the fracture of industrially manufactured bleached and unbleached spruce and pine fibers, also was observed different fracture mechanism for early- and latewood fibres. Earlywood fibers mostly crack in the pit areas, while latewood fibers crack in the areas of microdefects. The fracture usually appears perpendiculary to the longitudinal axis of the fiber.

The examination of thin wood strips reveals even more considerable differences between the tensile strength values of latewood and earlywood. The study of pine wood (Pinus sylvestris L.) strips with the thickness of approximately $70 \mu \mathrm{m}$ and the width of $10 \mathrm{~mm}$ showed that 
the tensile strength of latewood was 4 times higher than the one of earlywood [20].

After tensile testing the microstructure of the fractured samples was observed using SEM. In Fig. 5 the micrograph of spruce sample fracture zone is presented.

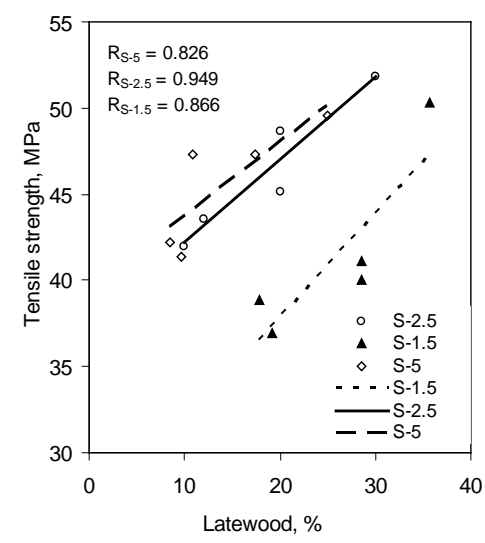

a

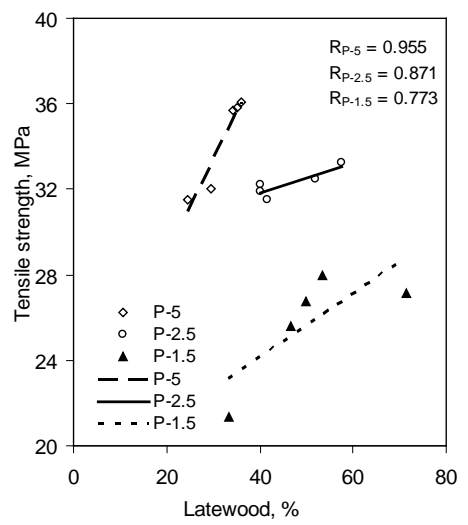

b

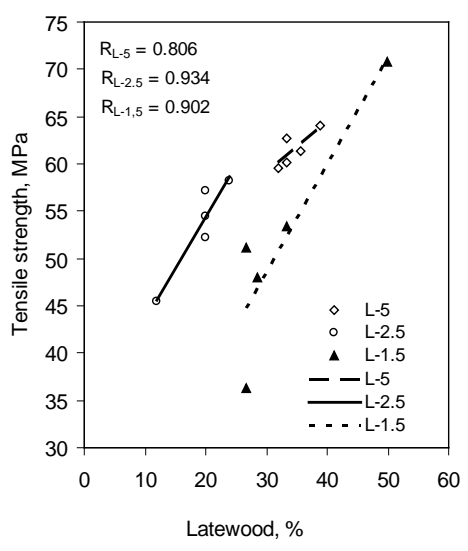

$\mathrm{C}$

Fig. 4. Dependence of tensile strength on the amount of latewood in the sample: $\mathrm{a}$ - spruce; $\mathrm{b}$ - pine; $\mathrm{c}$ - larch

Figure 5 shows that the fibers break non-uniformly and cells are strongly deformed. In some areas it can be seen microfibrils bundles separated from the cells. Also it is possible to distinguish that outer cells are affected prior to tensile testing during sample preparation time. When microtoming the sample, external cells are slightly deformed, thus reduces the strength of the whole sample. The examination of thin samples showed that the length of the working area also affects the tensile strength value.
Studies performed by other authors demonstrate that the tensile strength is lower in the presence of longer working length between the grips [20]. This can be explained by the presence of a larger amount of microdefects in longer samples and the occurrence of plastic deformations.

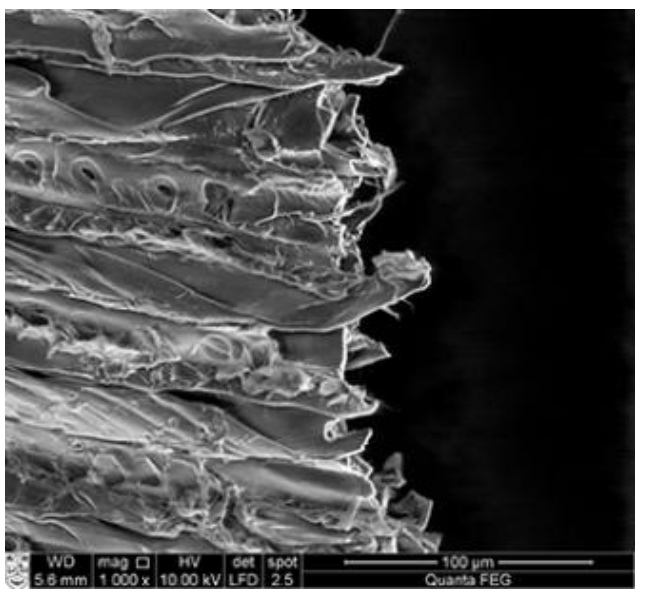

Fig. 5. SEM micrograp of the fracture zone of spruce sample, longitudinal section

Observing fracture trends of the samples, it was noticed that not all samples fracture in the same way. Some of the samples (mainly pine) failure immediately, while the others (mostly larch, sparsely - spruce) fracture in several stages (Fig. 6).

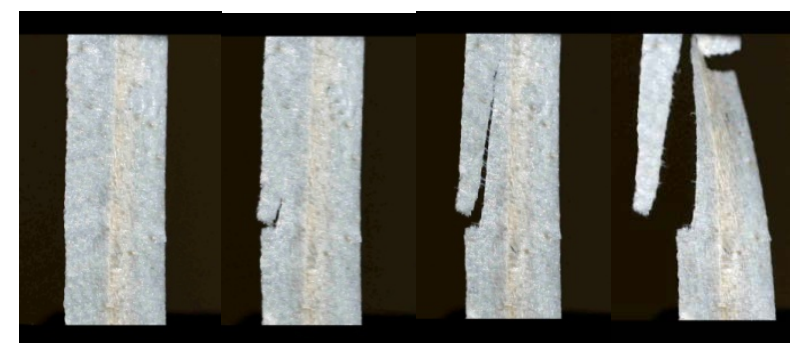

a

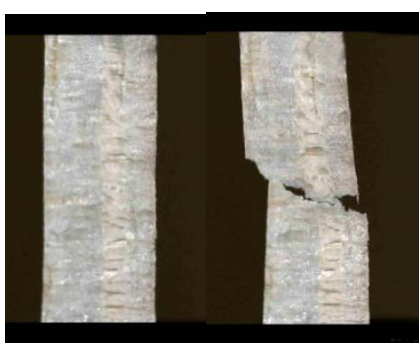

b

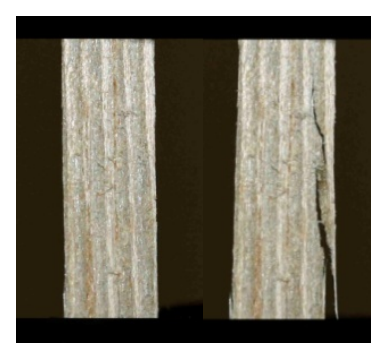

C
Fig. 6. Fracture behaviour of tissues: a - spruce, b - pine, c - larch; sample thickness $-100 \mu \mathrm{m}$, width $-5.0 \mathrm{~mm}$, working length $-16 \mathrm{~mm}$

Crack of spruce (Fig. 6, a) and pine (Fig. b) wood samples, usually with the largest width, initiates in the external region of the earlywood cells area and with increasing tension starts to grow, while the sample completely fractures. Similar behaviour was noticed for some larch wood samples - crack initiates in the edge of the sample, however crack development and failure of these samples is totally different compared to spruce and pine samples (Fig. 6, c). During tensile test first of all the earlywood allocated between latewood areas strongly 
failures and afterwards with increasing tensile force the latewood fibres fracture. Larch wood samples used in this study had particularly dense and narrow annual growth rings, where earlywood areas compared to the other studied wood types are very narrow (up to $1 \mathrm{~mm}$ in width). Therefore, although earlywood fractures quite rapidly, the sample breaks only by a relatively high tensile force.

\section{CONCLUSIONS}

Research results showed that larch wood tissues have higher strength up to $27 \%$ compared to spruce samples and up to $50 \%$ compared to pine samples. On the other hand, studies have shown that wood microstructure and particularly earlywood and latewood ratio in the sample have significant impact on the results of tensile strength and elasticity of wood samples. It was found that the results of the same wood species can vary on average $20 \%$, and in some cases even up to $25 \%-30 \%$.

Spruce wood is more prone to deformation and its cells are more elastic compared to other studied species. Prior to failure spruce wood samples extend up to $10 \%$, while pine wood samples - up to $6 \%$, and larch up to $5 \%$.

Also observation of the microstructure showed that sample preparation is critical for the microtensile testing. Microcracks, which occur during the preparation process, reduce the strength of fibre and contribute to the formation of the area within which cracking begins to develop. It can be stated that the smaller the measurements of samples, the more effect the preparation of samples will have on the obtained results and the more considerable dispersion of the obtained results will be present.

\section{REFERENCES}

1. Miller, B. R. Structure of Wood. Wood Handbook: Wood as an Engineering Material. Madison, WI: USDA Forest Service, Forest Products Laboratory, 1999: 486 p.

2. Gindl, W., Gupta, H. S., Schoberl, T., Lichtenegger, H. C., Fratzl, P. Mechanical Properties of Spruce Wood Cell Walls by Nanoindentation Materials Science and Processing 79 (8) 2004: pp. 2069-2073.

3. Brändström, J. Micro- and Ultrastructural Aspects of Norway Spruce Tracheids: a Review IAWA Journal 22 (4) 2001: pp. $333-353$.

4. Burgert, I., Echstein, D. The Tensile Strength of Isolated Wood Rays of Beech (Fagus Sylvatica) and Its Significance for the Biomechanics of Living Trees Trees 15 (3) 2001: pp. $168-170$.

5. Persson, K. Micromechanical Modelling of Wood and Fibre Properties. Doctoral Thesis. Lund: KFS Lund AB, 2000: $213 \mathrm{p}$.

6. Eder, M., Stanzl-Tschegg, S., Burgert, I. The Fracture Behaviour of Single Wood Fibres is Governed by Geometrical Constraints: in situ ESEM Studies on Three Fibre Types Wood Science and Technology 42 (8) 2008: pp. 679-679.

7. Hornatowska, J. Fracture Mechanisms Observed during Tensile Testing of Single Fibres Paper Mechanics Cluster and COST Action FP0802 2009.

8. Yu, Y., Jiang, Z., Fei, B., Wang, G., Wang, H. An Improved Microtensile Technique for Mechanical
Characterization of Short Plant Fibers: a Case Study on Bamboo Fibers Journal of Material Science 46 (3) 2011: pp. $739-746$.

9. Volkmer, T., Arietano, L., Plummer, C., Strautmann, J., Noël, M. Loss of Tensile Strength in Cellulose Tissue on the Surface of Spruce (Picea abies) Caused by Natural Photodegradation and Delignification Polymer Degradation and Stability 98 (6) 2013: pp. 1118-1125. http://dx.doi.org/10.1016/j.polymdegradstab.2013.03.019

10. Burgert, I., $\quad$ Frühmann, K., $\quad$ Keckes, J., $\quad$ Fratzl, P., Stanzl-Tschegg, S. Structure-function Relationships of Four Compression Wood Types: Micromechanical Properties at the Tissue and Fibre Level Trees 18 (4) 2004: pp. $480-485$.

11. Reiterer, A., Lichtenegger, H., Fratzl, P., Stanzl-Tschegg, S. Deformation and Energy Absorption of Wood Cell Walls with Different Nanostructure under Tensile Loading Journal of Materials Science 36 (19) 2001: pp. $4681-4686$. http://dx.doi.org/10.1023/A:1017906400924

12. Sedighi-Gilani, M., Navi, P. Experimental Observations and Micromechanical Modelling of Successive-damaging Phenomenon in Wood Cells' Tensile Behaviour Wood Science and Technology 41 (1) 2007: pp. 69-85. http://dx.doi.org/10.1007/s00226-006-0094-5

13. Keunecke, D., $\quad$ Eder, M., $\quad$ Burgert, I., Niemz, $\mathbf{P}$. Micromechanical Properties of Common Yew (Taxus Baccata) and Norway Spruce (Picea Abies) Transition Wood Fibers Subjected to Longitudinal Tension Journal of Wood Science 54 (5) 2008: pp. 420-422.

14. Eder, M., Arnould, O., Dunlop, J. W. C., Hornatowska, J., Salmen, L. Experimental Micromechanical Characterization of Wood Cell Walls Wood Science and Technology 47 (1) 2013: pp. 163-182.

15. Bergstedt, A., Lyck, C. Larch Wood - a Literature Review. Copenhagen: Hørsholm, 2007: 108 p.

16. Juodeikienè, I. Wood Structure. Textbook. Technologija, Kaunas, 2008: 84 p. (in Lithuanian).

17. Koizumi, A., Takata, K., Yamashita, K., Nakada, R. Anatomical Characteristics and Mechanical Properties of Larix Sibirica Grown in South-central Siberia IAWA Journal 24 (4) 2003: pp. 355-370.

18. Galicki, J., Czech, M. Tensile Strength of Softwood in LR Orthotropy Plane Mechanics of Materials 37 (6) 2005: pp. $677-686$. http://dx.doi.org/10.1016/j.mechmat.2004.07.001

19. Qing, H., Mishnaevsky, L. Jr. A 3D Multilevel Model of Damage and Strength of Wood: Analysis of Microstructural Effects Mechanics of Materials 43 (9) 2011: pp. 487-495. http://dx.doi.org/10.1016/j.mechmat.2011.05.007

20. Turkulin, H., Sell, J. Investigations into the Photodegradation of Wood Using Microtensile Testing. Part 4: Tensile Properties and Fractography of Weathered Wood Holz als Roh- und Werkstoff 60 2002: pp. 96-105.

21. Derbyshire, H., Miller, E. R., Turkulin, H. Investigations into the Photodegradation of Wood Using Microtensile Testing. Part 2: An Investigation of the Changes in Tensile Strength of Different Softwood Species during Natural Weathering Holz als Roh- und Werkstoff 54 1990: pp. $1-6$. http://dx.doi.org/10.1007/s001070050123 